\title{
EFFECT OF ADDING SOME ANTIOXIDANTS TO DIET CONTAINING FATTY ACIDS ON PRODUCTIVE AND SOME PHYSIOLOGICAL PARAMETERS OF SILVER MONTAZAH CHICKENS STRAIN. 2-DURING LAYING PERIOD
}

\author{
A. S. A. Bahakaim ${ }^{1}$; I. M. Assaf ${ }^{1}$; Sahar M.H. Osman' ${ }^{1}$; M. M. Soliman ${ }^{2}$ and A.M.A. Bealish ${ }^{2}$ \\ ${ }^{1}$ Department of Poultry Nutrition Research, Animal Production Research Institute, Agriculture Research \\ Center, Dokki, Giza \\ ${ }^{2}$ Department of Poultry and Breeding Research, Animal Production Research Institute, Agriculture \\ Research Center, Dokki, Giza
}

(Received 15/10/2018, accepted 4/12/2018)

\section{SUMMARY}

\begin{abstract}
A $\mathrm{n}$ experiment was conducted for a period of $12 \mathrm{wks}$ to investigate the effect of some antioxidants in the diet on productive performance and some physiological and hematological parameters as well as fertility and hatchability of chickens. For this purpose, 231 Silver Montazah strain birds (210 hens and 21 cocks) 24-wks-old were used in this experiment up to 36 wks of age. All birds were individually weighed and randomly divided into 7 equal experimental groups (30 hens and 3 cocks of each) with three replicates (10 hens and 1 cock each) with almost similar initial average body weight. Replicates were randomly housed in floor pens ( $280 \mathrm{~cm}$ long x $220 \mathrm{~cm}$ wide). The $1^{\text {st }}$ group was fed the basal diet that supplemented linoleic acid (n-6) and linolenic acid (n-3) at the ratio of 4:1, respectively and served as control. The $2^{\text {nd }}$ and $3^{\text {rd }}$ groups were fed the basal diet supplemented with 125 and $250 \mathrm{~g}$ Butylated Hydroxy Toluene/ton diet, respectively. The $4^{\text {th }}$ and $5^{\text {th }}$ groups were fed the basal diet supplemented with 100 and $200 \mathrm{~g}$ vit. E /ton diet, respectively. The $6^{\text {th }}$ and $7^{\text {th }}$ groups were fed the basal diet supplemented with 5 and $10 \mathrm{~kg}$ citric acid/ton diet, respectively. Results indicated that antioxidants supplementation significantly increased egg number, egg production percentage and egg mass and improved feed conversion ratio and egg shell thickness compared to the control group. Moreover, significant increase was obtained for blood hemoglobin, red blood cells and white blood cells, as well as plasma total protein, globulin and high density lipoproteins for groups fed antioxidants compared with the control group. Ejaculate volume, sperm motility, live sperm percentage, sperm concentration, total sperm per ejaculate and total live sperm per ejaculate, as well as fertility and hatchability percentages were increased. Conversely, significant lower heterophils/lymphocytes ratio and plasma concentration of total lipids, cholesterol, triglycerides and lowdensity lipoproteins were associated with supplemental antioxidants, while abnormal sperm percentage was decreased with antioxidants supplementation. In conclusion, dietary supplemental of some antioxidants to feed containing fatty acids is a practical application recommended especially by 100 and $200 \mathrm{~g}$ vit. E or $10 \mathrm{~kg}$ citric acid/ton diet to Silver Montazah chickens strain during the laying period and had beneficial effects on productive, reproductive, physiological and hematological parameters and immune status.
\end{abstract}

Keywords: antioxidants, chickens, productive performance, physiological and hematological parameters, fertility and hatchability.

\section{INTRODUCTION}

In avian species, alpha linolenic acid (18:3 n-3) and linoleic acid (18:2 n-6) cannot be synthesized in the body and have to be supplied in the diet, therefore they are called essential fatty acids. Fatty acids are the major components of chicken egg yolk lipids and constitute over $4 \mathrm{~g} / \mathrm{egg}$ on the average. From a nutritional standpoint of view, yolk fatty acids are the major source of energy and long-chain $\mathrm{C}_{20}$ and $\mathrm{C}_{22}$ polyunsaturated fatty acids (PUFA) are essential for developing chick during embryogenesis (Cherian, 2007). It is interest to note that the ratio of $n-6 / n-3$ PUFA appears to be more important for fat and cholesterol metabolism and in modulating antibody synthesis than the absolute concentrations of n-3 PUFA in the diet (Sijben et al., 2000). So, there is a need to regulate the intake of n-6 and n-3 PUFA in balanced proportions. Feeding either 4:1 or 6:1 linoleic acid (LA) to linolenic acid (LNA) containing diet improving productive 


\section{Bahakaim et al.}

performance, enhancing fertility and hatchability, produced low triglycerides, cholesterol and rich in PUFA eggs in laying hens (Radwan et al., 2012).

Synthetic antioxidants, such as butylated hydroxytoluene (BHT), can inhibit lipid oxidation in feed but they have toxic properties (Kahl and Kappus, 1993) resulting in strict regulations over their use in foods. These findings, together with increased resistance to the use of synthetic additives, have increased interest in the antioxidant properties of naturally occurring substances (Gordon, 1996).

Vitamin E (vit. E) is a metabolic nutrient that has received a lot of attention with respect to its importance to the immune response in poultry. However, chicken cannot synthesis vit. E, therefore, its requirements must be given from dietary sources (Chan and Decker, 1994). Also, vit. E has been reported as a natural antioxidant. It prevents the oxidation of unsaturated lipid materials within cells, thus protecting the cell membrane oxidative damage (Gore and Qureshi, 1997). Furthermore, vit. E serves as a physiological antioxidant through inactivation of free radicals. As well as, it improves egg production, feed intake, egg yolk and albumen solids (Kirunda et al., 2001), and improved growth performance and immune response in Inshas chickens (Alm El-Dein et al., 2013).

Citric acid (CA) is one of the most widely used food additives, which is commonly used as a preservative, acidulant, $\mathrm{pH}$ control agent, flavor enhancer, and antioxidant in many foods (Kristiansen et al., 1999). Al-Harthi and Attia (2015) found that feed intake and feed conversion ratio were significantly affected by CA supplementation in laying hens, the positive effect of CA on feed intake may be due to the effect of maintaining feed freshness and thus the palatability of the feed. High levels of calcium in the laying hens diets may interfere with $\mathrm{CA}$ affecting $\mathrm{pH}$ in the gut towards alkalinity, thus reducing its effectiveness as an acidic agent (Nezhad et al., 2007).

Therefore, the objectives of this experiment were to study the effect of adding some antioxidants to feed containing fatty acids on productive and reproductive performance and some physiological and hematological parameters of Silver Montazah (SM) chickens strain during the laying period (24-36 weeks of age).

\section{MATERIALS AND METHODS}

This experiment was carried out at Inshas Poultry Breeding Station, Animal Production Research Institute, Agricultural Research Center, Egypt.

\section{Chicks and experimental design:}

A total number of 231 Silver Montazah (SM) strain birds (210 hens and 21 cocks) 24-wks-old were used in this experiment up to $36 \mathrm{wks}$ of age. All birds were individually weighed and randomly divided into 7 equal experimental groups ( 30 hens and 3 cocks of each) with three replicates (10 hens and 1 cock each) with almost similar initial average body weight. Replicates were randomly housed in floor pens $(280 \mathrm{~cm}$ long x $220 \mathrm{~cm}$ wide). The $1^{\text {st }}$ group was fed the basal diet that contained linoleic acid (n-6) and linolenic acid $(n-3)$ at the ratio of $4: 1$, respectively and served as control. The $2^{\text {nd }}$ and $3^{\text {rd }}$ groups were fed the basal diet supplemented with 125 and $250 \mathrm{~g} \mathrm{BHT/ton} \mathrm{diet,} \mathrm{respectively.} \mathrm{The} 4^{\text {th }}$ and $5^{\text {th }}$ groups were fed the basal diet supplemented with 100 and $200 \mathrm{~g}$ vit. E /ton diet, respectively. The $6^{\text {th }}$ and $7^{\text {th }}$ groups were fed the basal diet supplemented with 5 and $10 \mathrm{~kg} \mathrm{CA} /$ ton diet, respectively.

\section{Managements and feeding:}

All birds were kept under the same managerial hygienic and environmental conditions. Birds were kept in a windowed house with light cycle regimen of $16 \mathrm{~h}$ light: $8 \mathrm{~h}$ darkness, throughout the experimental period (24-36 wks of age). Feed and water were provided for ad libitum consumption. The basal experimental diet was formulated to meet the nutrient requirements of SM laying hens during period from (24-36 wks of age) according to feed composition tables for animal and poultry feed stuffs used in Egypt (2001). The composition and calculated analysis of the experimental basal diet is present in (Table 1). 
Egyptian J. Nutrition and Feeds (2018)

Table (1): Composition and calculated analyses of the experimental basal diet.

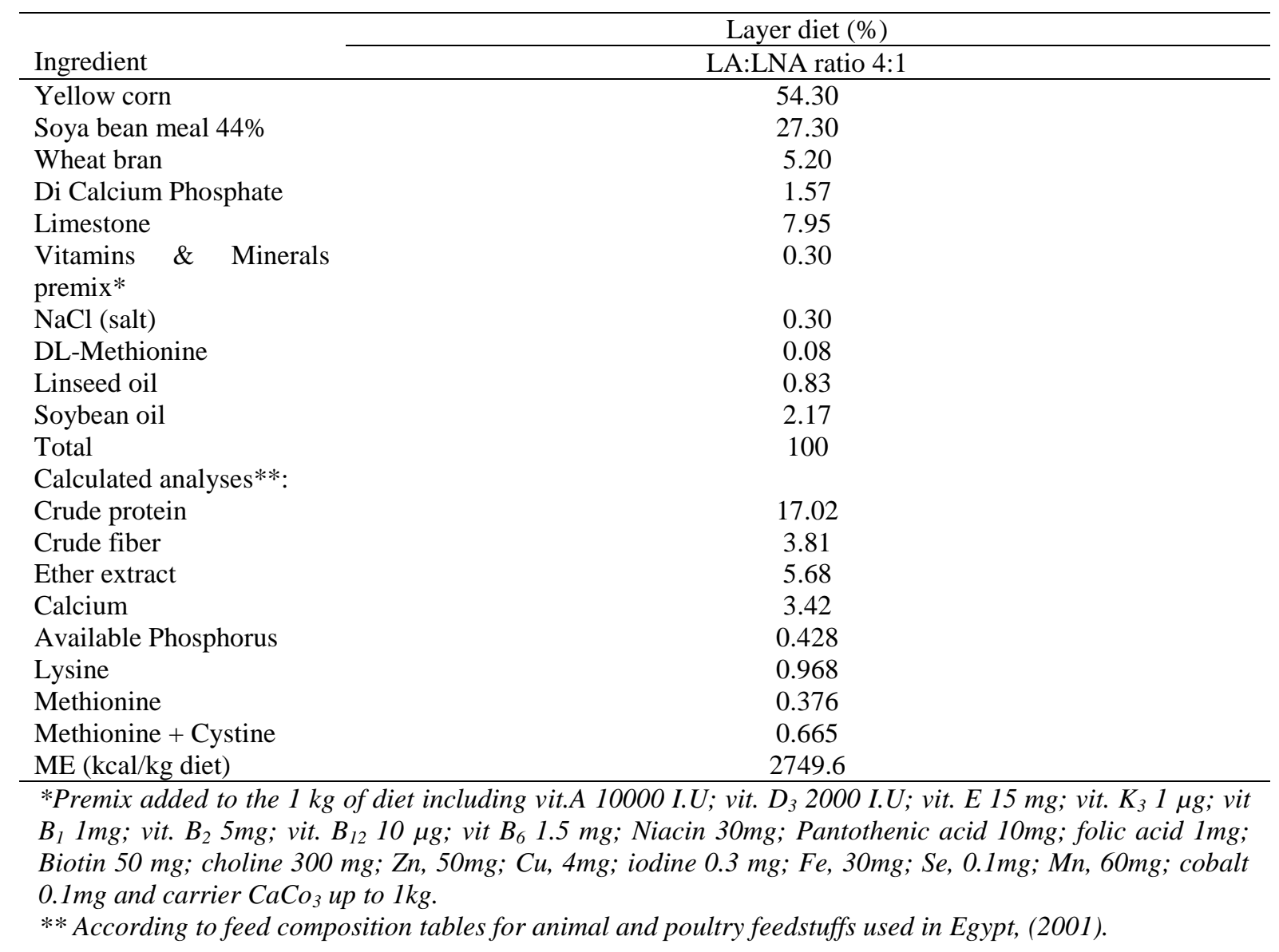

\section{Laying performance traits:}

Body weights were recorded at the beginning (24 weeks of age) and the end of the experiment (36 weeks of age). Feed intake and feed conversion ratio (FCR), egg number and egg production percentage, egg weight and egg mass (number of eggs $\mathrm{x}$ egg weight) were recorded for each replicate at the end of each week from 24 up to 36 wks of age.

\section{Egg quality parameters:}

A total of 105 eggs (15 eggs from each treatment) were taken after 36 wks of age to determine the interior and exterior egg quality parameters. Eggs were weighed individually then broken and the inner contents were placed on a leveled glass surface to determine the inner egg quality. The inner egg quality parameters included shell weight \% (SW), shell thickness, mm (ST) including shell membranes which was measured using a micrometer at three locations on the egg (air cell, equator and sharp end), egg length, cm (EL), egg width, cm (EWd), shape index (SI) which was estimated as the percentage of (EWd) to (EL), albumen weight \% (AW), yolk weight \% (YW), yolk height, mm (YH), yolk diameter, mm (YD) and yolk index (YI) which was estimated as the percentage of YH to YD.

\section{Blood biochemical analysis and hematological picture:}

At 36 wks of age (end of experiment), six blood samples were collected from each experimental treatment from the wing vein in two heparinized test tubes. Blood of the first tube was used to evaluate the total count of red and white blood cells, and blood smears were done and stained with Fleishman's stain for the differential counts of leucocytes. The other blood tube was centrifuged at $3000 \mathrm{rpm}$ for $15 \mathrm{~min}$, so plasma samples were harvested and stored at $-20^{\circ} \mathrm{C}$ until the time of biochemical analysis. Commercial kits were used for colorimetrically determination of the following blood plasma constituents according to procedure outlined by the manufacturer. Total protein and albumin, total lipids, total cholesterol, high density lipoproteins (HDL), low density lipoproteins (LDL), and hepatic enzymes including aspartate amino 


\section{Bahakaim et al.}

transaminase (AST) and alanine amino transaminase (ALT) were determined. Globulin was calculated by subtraction of plasma albumin from total protein, and albumin/globulin ratio was calculated.

\section{Semen quality:}

Semen samples were collected randomly from 21 cocks ( 3 cocks of each treatment) at 36 weeks of age using the massage method. Semen samples were examined for the following characteristics.

1-The ejaculate volume was determined to the nearest $0.01 \mathrm{ml}$. using $1.00 \mathrm{ml}$. tuberculin syringe.

2-Mass motility score (from 1 to 5 grades).

3-Percentage of live and abnormal sperm was determined after staining with iosine and nigrosine.

4-Sperm concentration was determined by using Thomes - Zeis haemocytometer.

5 -Total sperm/ejaculate $\times 10^{9}=$ (ejaculate volume $\mathrm{x}$ sperm concentration).

6-Total abnormal sperm/ejaculate x $10^{9}=($ abnormal sperm $\%$ x total sperm/ejaculate $/ 100)$.

7-Total live sperm/ejaculate $\times 10^{9}=($ live sperm\% $\mathrm{x}$ total sperm/ejaculate /100).

The previous characteristics were determined according to Kalamah et al, (2000).

\section{Fertility and hatchability:}

Eggs from each treatment were collected through one week at the end of experimental period (36 wks of age), to study the fertility and hatchability\% as follows:-

Fertility $\%=($ Number of fertile eggs x 100) / Total eggs set

Hatchability\% 1 = (Number of hatched chicks $x 100) /$ Total number of eggs

Hatchability\% 2 = (Number of hatched chicks x 100)/ Total number of fertile eggs

\section{Statistical analysis:}

Data were subjected to one-way analysis of variance using SAS (2001). Differences among means were detected by using Duncan's multiple range test (Duncan, 1955). The percentage values were transferred to percentage angle using arcsine equation before subjected to statistical analysis, and then actual means are presented. The following model was used:

$$
\mathrm{Yij}=\mu+\mathrm{Ti}+\mathrm{eij} .
$$

Where, Yij = an observation for each dependent variable; $\mu=$ overall mean;

$\mathrm{Ti}=$ Treatment effects $(\mathrm{i}=1,2 \ldots$ and 7$) ; \quad$ eij $=$ experimental random error.

\section{RESULTS AND DISCUSSION}

\section{Laying performance:}

Results obtained from Table (2) showed a non-significant difference among antioxidant treatment groups for final body weight and body weight gain (change in body weight) at the end of the experimental period (36wk old) as compared to the control group. On the other hand, there was a significant difference $(\mathrm{P} \leq 0.05)$ among antioxidant treatment groups (except CA groups) for feed intake values compared with control group. However, the hens fed diet contains BHT or vit. E groups consumed diet significantly $(\mathrm{P} \leq 0.05)$ less than control group. Moreover, FCR ( $\mathrm{g}$ feed/g egg) and laying performance parameters (egg number, egg production $\%$ and egg mass) were significantly $(\mathrm{P} \leq 0.05)$ improved in the hens fed diet containing different types and levels of antioxidant compared with the control group. In this respect, antioxidant such as vit. E act during the initiation stage, slowing the generation of free radicals (Carrillo-Dominguez et al., 2012). Vit. E acts using at least two different mechanisms. Firstly, it directly scavenges the free radicals through modulates the expression of genes that are required by free radical signaling, and this free radicals damage cell membranes by inducing lipid peroxidation of polyunsaturated fatty acids in the cell membrane (Packer et al., 1997). Secondly, vit. E increases the activity of antioxidant enzymes such as superoxide dismustage, glutathione peroxidase, glutathione reductase, catalase and nicotinamide adenine dinucllotide phosphate, which considered the enzymatic defense system against free radicals and protecting cells against oxidative damage, also, vit. E has known to reduce $\mathrm{Fe}^{++}$induced lipid peroxidation (Vertuani et al., 2004). 
Table (2): Effect of adding some antioxidants to diet containing fatty acids on the performance of Silver Montazah laying hens during the period from 24 to 36 weeks of age.

\begin{tabular}{|c|c|c|c|c|c|c|c|c|}
\hline \multirow[t]{2}{*}{ Item } & \multicolumn{8}{|c|}{ Treatments/ton diet } \\
\hline & $\begin{array}{l}\text { Control }^{1} \\
\text { (C) }\end{array}$ & $\begin{array}{c}\mathrm{C}+125 \mathrm{~g} \\
\mathrm{BHT}^{2}\end{array}$ & $\begin{array}{c}\mathrm{C}+250 \mathrm{~g} \\
\mathrm{BHT}\end{array}$ & $\begin{array}{l}\mathrm{C}+100 \mathrm{~g} \\
\text { vit. } \mathrm{E}\end{array}$ & $\begin{array}{c}\mathrm{C}+200 \mathrm{~g} \\
\text { vit. } \mathrm{E}\end{array}$ & $\begin{array}{c}\mathrm{C}+5 \mathrm{~kg} \\
\text { citric acid }\end{array}$ & $\begin{array}{l}\mathrm{C}+10 \mathrm{~kg} \\
\text { citric acid }\end{array}$ & $\pm \mathrm{SEM}^{3}$ \\
\hline $\begin{array}{l}\text { Initial } \\
\text { body } \\
\text { weight }(\mathrm{g})\end{array}$ & 1373.73 & 1376.93 & 1376.63 & 1376.30 & 1375.17 & 1376.63 & 1379.30 & 1.946 \\
\hline $\begin{array}{l}\text { Final body } \\
\text { weight }(\mathrm{g})\end{array}$ & 1517.93 & 1531.20 & 1534.43 & 1547.97 & 1565.73 & 1543.10 & 1546.83 & 17.311 \\
\hline $\begin{array}{l}\text { Change in } \\
\text { body } \\
\text { weight }(\mathrm{g})\end{array}$ & 144.20 & 154.27 & 157.80 & 171.67 & 190.57 & 166.47 & 167.53 & 16.946 \\
\hline $\begin{array}{l}\text { Total feed } \\
\text { intake } \\
(\mathrm{g} / \mathrm{hen})\end{array}$ & $9286.00^{\mathrm{a}}$ & $9061.67^{c}$ & $9110.00^{\mathrm{bc}}$ & $9163.00^{\mathrm{bc}}$ & $9163.33^{\mathrm{bc}}$ & $9193.67^{\mathrm{ab}}$ & $9170.67^{\mathrm{abc}}$ & 36.741 \\
\hline $\begin{array}{l}\text { Feed } \\
\text { conversion } \\
(\mathrm{g} \text { feed/g } \\
\text { egg) }\end{array}$ & $4.783^{\mathrm{a}}$ & $3.837^{\mathrm{b}}$ & $3.873^{\mathrm{b}}$ & $3.837^{\mathrm{b}}$ & $3.833^{\mathrm{b}}$ & $3.903^{\mathrm{b}}$ & $3.890^{\mathrm{b}}$ & 0.049 \\
\hline $\begin{array}{l}\text { Egg } \\
\text { number }\end{array}$ & $44.33^{\mathrm{b}}$ & $53.60^{\mathrm{a}}$ & $53.59^{\mathrm{a}}$ & $54.39^{\mathrm{a}}$ & $54.42^{\mathrm{a}}$ & $53.54^{\mathrm{a}}$ & $53.78^{\mathrm{a}}$ & 0.507 \\
\hline $\begin{array}{l}\text { Egg } \\
\text { production } \\
(\%)\end{array}$ & $52.78^{\mathrm{b}}$ & $63.81^{\mathrm{a}}$ & $63.80^{\mathrm{a}}$ & $64.74^{\mathrm{a}}$ & $64.79^{\mathrm{a}}$ & $63.74^{\mathrm{a}}$ & $64.03^{\mathrm{a}}$ & 0.603 \\
\hline $\begin{array}{l}\text { Egg } \\
\text { weight } \\
\text { (g) }\end{array}$ & 43.83 & 44.07 & 43.88 & 43.90 & 43.95 & 43.98 & 43.84 & 0.141 \\
\hline $\begin{array}{l}\text { Egg mass } \\
(\mathrm{g})\end{array}$ & $1943.14^{\mathrm{b}}$ & $2362.23^{\mathrm{a}}$ & $2351.67^{\mathrm{a}}$ & $2387.55^{\mathrm{a}}$ & $2391.96^{\mathrm{a}}$ & $2354.76^{\mathrm{a}}$ & $2357.98^{\mathrm{a}}$ & 22.104 \\
\hline
\end{tabular}

Accordingly results in the present study demonstrated that the high level of vit. E (150 mg/kg diet) resulted in significantly $(\mathrm{P} \leq 0.05)$ better value of FCR in laying periods compared to either low levels or control group, and this effect reflected on 1) improvement in body weight in laying period 2) earlier age of sexual maturity with significance $(\mathrm{P} \leq 0.05)$ for chickens in this group compared to low levels and control group (Alm El-Dein et al., 2017). Panda et al. (2008) found that the high level of vit. E (125 IU/kg diet) significantly improved FCR compared to the low level (25 IU/kg diet) in White Leghorn layers. Concerning body weight, Sahin et al. (2002) reported that supplementation of $250 \mathrm{mg} / \mathrm{kg}$ diet vit. E significantly $(\mathrm{P} \leq 0.05)$ increased body weight in laying Japanese quail as compared to $125 \mathrm{mg} / \mathrm{kg}$ diet and control group.

The highest level of vit. E significantly $(\mathrm{P} \leq 0.05)$ improved egg production more than other low levels and control group. This may be because vit. E playing an important role in, 1) enhancing synthesis of egg yolk precursors (vitellogenin and very low density lipoprotein) in the liver through its action as an antioxidant which protect the liver from lipid peroxidation and damage to the cell membrane and 2) facilitating the release of the previous precursors from the liver and increasing the circulating supply of them for yolk formation (Bollengier-Lee et al., 1998 and 1999 and Puthpon-Gsiriporn et al., 2001). Results reported herein for egg production support the previous finding of Panda et al. (2008) who reported that, increasing the level of vit. E from 25 to $125 \mathrm{IU} / \mathrm{kg}$ diet significantly improved egg production.

Alm El-Dein et al. (2017) found that, adding different levels of vit. E to laying hen's diet increased hen productive performance significantly $(\mathrm{P} \leq 0.05)$ in terms of egg number, egg production percentage and egg mass and without significant effects on body weight gain and egg weight compared to control group, although, total feed intake had comparable values (slight increase) among all experimental groups compared to control group. Consequently, the presence of anti-oxidants (vit.E) could partially interfere with oxidative protein denaturation and thereby improving its digestibility thus reflect on hen productivity (Ciftci et al., 2005). Similar trends were reported by Metwally (2003); El-Mallah et al. (2011); Alm El-Dein et al. (2013) 
and Younis (2014) who showed a significant increase in egg production for the group supplemented with $450 \mathrm{mg}$ vit. E/kg diet as compared with control group. It may be attributed to the role of vit. E. Also, vit.E increased egg productivity by preventing liver cell damage which is important in egg yolk synthesis (Kirunda et al., 2001).

Al-Harthi and Attia (2015) found that feed intake and FCR were significantly affected by CA supplementation in laying hens, the positive effect of CA on feed intake may be due to the effect of maintaining feed freshness and thus the palatability of the feed. High levels of calcium in the laying hens' diets may interfere with $\mathrm{CA}$ affecting $\mathrm{pH}$ in the gut towards alkalinity, thus reducing its effectiveness as an acidic agent (Nezhad et al., 2007). In the literature, CA supplementation has been reported to preserve freshness and to decrease microbial growth and harmful bacteria $(E$. Coli $)$, thereby maintaining feed quality during storage and in the gut and leading to better animal growth (Deepa et al., 2011).

\section{Egg quality:}

Concerning external and internal egg quality traits, Table (3) showed that hens fed diets provided with antioxidant improved significantly $(\mathrm{P} \leq 0.05)$ shell thickness as compared with the hens in the control group. However, the hens fed diet contains $125 \mathrm{~g}$ BHT/ton diet recorded significantly $(\mathrm{P} \leq 0.05)$ higher yolk $(\%)$ compared with control group. Moreover, yolk index was significantly $(\mathrm{P} \leq 0.05)$ increased in the hens fed diet containing the highest level of vit. E (200g/ton diet) compared with hens fed diet containing the lowest level of vit. E (100g/ton diet). These results agreed with the findings of Al-Harthi and Attia (2015) who indicated that adding $0.2 \% \mathrm{CA}$ to laying hens diets significantly improved eggshell quality compared to adding $0.1 \%$ CA. In the literature, CA supplementation at $0.15-0.2 \%$ improved eggshell quality. This is probably due to the positive impact of $\mathrm{CA}$ on phytate phosphorus utilization and thus on the release of minerals bound to the phytate molecule (Islam, 2012 and Kaya et al., 2014). In the literature, organic acids was found to promote the growth of the epithelial cells of the intestine and thereby improve the absorption and metabolism of calcium (Langhout and Sus, 2005) and improve the digestion and absorption of nutrients (Vogt, 2001 and Kaya et al., 2014). El-Mallah et al. (2011) showed that most egg quality parameters were not affected $(\mathrm{P} \leq 0.05)$ by adding the vit. E at either level 0.20 or $0.40 \mathrm{mg} / \mathrm{kg}$ except, shape index which was significantly $(\mathrm{P} \leq 0.05)$ decreased and shell thickness which significantly $(\mathrm{P} \leq 0.05)$ improved compared to the control.

Table (3): Effect of adding some antioxidants to diet containing fatty acids on external and internal egg quality of Silver Montazah laying hens at 36 weeks of age.

\begin{tabular}{|c|c|c|c|c|c|c|c|c|}
\hline \multirow[t]{2}{*}{ Item } & \multicolumn{8}{|c|}{ Treatments/ton diet } \\
\hline & $\begin{array}{c}\text { Control }^{1} \\
\text { (C) }\end{array}$ & $\begin{array}{c}\mathrm{C}+125 \mathrm{~g} \\
\mathrm{BHT}^{2}\end{array}$ & $\begin{array}{c}\mathrm{C}+250 \mathrm{~g} \\
\mathrm{BHT}\end{array}$ & $\begin{array}{l}\mathrm{C}+100 \mathrm{~g} \\
\text { vit. } \mathrm{E}\end{array}$ & $\begin{array}{c}\mathrm{C}+200 \mathrm{~g} \text { vit. } \\
\text { E }\end{array}$ & $\begin{array}{c}\mathrm{C}+5 \mathrm{~kg} \\
\text { citric acid }\end{array}$ & $\begin{array}{c}\mathrm{C}+10 \mathrm{~kg} \\
\text { citric acid }\end{array}$ & $\pm \mathrm{SEM}^{3}$ \\
\hline \multicolumn{9}{|c|}{ External egg quality } \\
\hline Egg length $(\mathrm{mm})$ & 53.78 & 52.12 & 52.24 & 51.78 & 51.56 & 51.64 & 52.54 & 0.897 \\
\hline Egg width (mm) & 41.56 & 41.08 & 40.56 & 41.22 & 40.90 & 40.90 & 40.98 & 0.639 \\
\hline Shell thickness (mm) & $0.332^{\mathrm{b}}$ & $0.376^{\mathrm{a}}$ & $0.378^{\mathrm{a}}$ & $0.372^{\mathrm{a}}$ & $0.370^{\mathrm{a}}$ & $0.374^{\mathrm{a}}$ & $0.372^{\mathrm{a}}$ & 0.004 \\
\hline Shell weight (\%) & 13.08 & 13.58 & 13.47 & 14.26 & 14.80 & 14.25 & 13.89 & 0.975 \\
\hline Egg shape index & 77.30 & 78.91 & 77.66 & 77.67 & 79.32 & 77.92 & 78.05 & 1.015 \\
\hline \multicolumn{9}{|c|}{ Internal egg quality } \\
\hline Albumen height (mm) & 6.43 & 7.08 & 6.70 & 7.61 & 6.74 & 6.87 & 7.22 & 0.955 \\
\hline Albumen (\%) & 57.28 & 53.40 & 54.37 & 53.14 & 53.32 & 52.95 & 54.27 & 1.518 \\
\hline Yolk height (mm) & 16.91 & 17.12 & 16.79 & 16.02 & 17.05 & 16.62 & 15.95 & 0.450 \\
\hline Yolk diameter & 39.18 & 38.84 & 39.20 & 39.64 & 37.44 & 38.66 & 39.18 & 0.804 \\
\hline Yolk (\%) & $29.63^{b}$ & $33.01^{\mathrm{a}}$ & $32.16^{\mathrm{ab}}$ & $32.60^{\mathrm{ab}}$ & $31.88^{\mathrm{ab}}$ & $31.86^{\mathrm{ab}}$ & $31.54^{\mathrm{ab}}$ & 0.949 \\
\hline Yolk index & $43.21^{\mathrm{ab}}$ & $44.15^{\mathrm{ab}}$ & $42.93^{\mathrm{ab}}$ & $40.52^{b}$ & $45.52^{\mathrm{a}}$ & $43.00^{\mathrm{ab}}$ & $40.89^{\mathrm{ab}}$ & 1.443 \\
\hline
\end{tabular}

\footnotetext{
$a, b, c$...Means within the same row with different superscripts are significantly differ $(P \leq 0.05) . \quad$ Control $^{l}$ basal diet containing linoleic acid (n-6) and linolenic acid (n-3) at the ratio of 4:1, respectively $B H T^{2}$ butylated hydroxyl toluene
}

${ }^{3}$ Pooled SEM

These results confirmed those of El-Sheikh and Salama (2010) who reported that vit E improved shell thickness and haugh unit score as compared to the control but, did not affect significantly shell weight and albumen weight $\%$ as compared to control, Similar results were reported by Eng-elmann et al. (2001), Kirunda et al. (2001) and Abd-El-Galil and Abd El-Samad (2004). In this connection, the achieved 
improvement in shell-thickness could be due to enhancement of calcium bioavailability by the action of supplemental vit. E. These facts confirmed the results of increased serum Ca concentration that has been established in the present study (Abdel-Fattah and Abdel-Azeem, 2007).

\section{Hemato-biochemical parameters:}

The results in Table (4) showed that vit. E treated laying hens had significantly ( $\mathrm{P} \leq 0.05)$ higher RBC's and WBC's number compared with control group. On the other hand, heterophils/ lymphocytes ratios were significantly $(\mathrm{P} \leq 0.05)$ lower due to adding the highest level of CA $(10 \mathrm{~kg} / \mathrm{ton})$ to laying hens diet compared with both the lowest level of CA ( $5 \mathrm{~kg} / \mathrm{ton})$ and control groups. While, adding different types and levels of antioxidants to laying hens diet had significantly $(\mathrm{P} \leq 0.05)$ higher hemoglobin compared with control group. Belong to cell mediated immunity, vit. $\mathrm{E}$ has been reported to protect the cells involved in the immune response (lymphocytes, macrophages and plasma cells) against oxidative damage and enhance the function and proliferation of these cells through maintain the macrophage membrane integrity which are needed for phagocytosis (Gore and Qureshi, 1997). Thus, Latshaw (1991) indicated that high levels of vit. E greater than 10 times the required level (recommend 5 to $25 \mathrm{IU}$ of vit-E/kg of diet according to (NRC, 1994) were immunostimulatory in chicks. Younis (2014) revealed a significant increase in total RBC count, $\mathrm{Hb}$ concentration, PCV\%, heart glycogen and a significant improving in glucose, triglycerides, ALT, AST and liver glycogen concentration due to supplementation of broiler breeders diet with vit. E.

Table (4): Effect of adding some antioxidants to diet containing fatty acids on hematological picture of Silver Montazah laying hens at 36 weeks of age.

\begin{tabular}{|c|c|c|c|c|c|c|c|c|}
\hline \multirow[t]{2}{*}{ Item } & \multicolumn{8}{|c|}{ Treatments/ton diet } \\
\hline & $\begin{array}{l}\text { Control }^{1} \\
\text { (C) }\end{array}$ & $\begin{array}{c}\mathrm{C}+125 \mathrm{~g} \\
\mathrm{BHT}^{2}\end{array}$ & $\begin{array}{c}\mathrm{C}+250 \mathrm{~g} \\
\mathrm{BHT}\end{array}$ & $\begin{array}{c}\mathrm{C}+100 \mathrm{~g} \\
\text { vit. } \mathrm{E}\end{array}$ & $\begin{array}{l}\mathrm{C}+200 \mathrm{~g} \\
\text { vit. } \mathrm{E}\end{array}$ & $\begin{array}{c}\mathrm{C}+5 \mathrm{~kg} \\
\text { citric } \\
\text { acid }\end{array}$ & $\begin{array}{c}\mathrm{C}+10 \mathrm{~kg} \\
\text { citric } \\
\text { acid }\end{array}$ & $\pm \mathrm{SEM}^{3}$ \\
\hline $\begin{array}{l}\text { Red blood cells } \\
\left(\mathrm{x} 10^{6} / \mu \mathrm{l}\right)\end{array}$ & $2.067^{b}$ & $2.367^{\mathrm{ab}}$ & $2.407^{\mathrm{ab}}$ & $2.607^{\mathrm{a}}$ & $2.581^{\mathrm{a}}$ & $2.473^{a b}$ & $2.300^{\mathrm{ab}}$ & 0.131 \\
\hline Hemoglobin & $10.800^{b}$ & $13.333^{\mathrm{a}}$ & $13.167^{\mathrm{a}}$ & $14.033^{\mathrm{a}}$ & $13.920^{\mathrm{a}}$ & $\underset{\mathrm{a}}{13.367}$ & $13.00^{\mathrm{a}}$ & 0.683 \\
\hline Hematocrit & 35.767 & 35.000 & 39.733 & 36.200 & 35.090 & 39.833 & 33.100 & 2.820 \\
\hline $\begin{array}{l}\text { White blood } \\
\text { cells }\left(\times 10^{3} / \mu \mathrm{l}\right)\end{array}$ & $5.600^{\mathrm{b}}$ & $6.767^{\mathrm{ab}}$ & $7.100^{a b}$ & $8.067^{\mathrm{a}}$ & $7.940^{\mathrm{a}}$ & $6.567^{a b}$ & $6.900^{\mathrm{ab}}$ & 0.528 \\
\hline Heterophil (\%) & 29.400 & 28.133 & 28.200 & 27.967 & 27.090 & 28.133 & 27.800 & 0.585 \\
\hline Lymphocyte (\%) & 59.467 & 59.733 & 59.833 & 58.967 & 58.310 & 60.533 & 60.900 & 0.782 \\
\hline $\begin{array}{l}\text { Heterophil/ } \\
\text { Lymphocyte ratio }\end{array}$ & $0.495^{\mathrm{a}}$ & $0.471^{\mathrm{ab}}$ & $0.471^{a b}$ & $0.474^{\mathrm{ab}}$ & $0.460^{\mathrm{ab}}$ & $0.495^{\mathrm{a}}$ & $0.456^{\mathrm{b}}$ & 0.010 \\
\hline
\end{tabular}

Concerning biochemical parameters, data of some plasma blood constituent of Silver Montazah laying hens as affected by feeding diet containing varying types and levels of antioxidant are presented in (Table 5). It is clear that the effect of antioxidant supplementation was more pronounced in laying hens on plasma lipids and proteins, thus plasma total lipids, cholesterol and triglycerides concentrations were decreased significantly. On the contrary, plasma total protein and globulin were increased significantly. However, plasma level of LDL was significantly the lowest for the vit. E supplemented groups at different levels and CA supplemented group at the highest level $(10 \mathrm{~kg} / \mathrm{ton}$ diet $)$, but plasma level of HDL was significantly higher for the vit. E supplemented group at higher level (200 g/ton diet) comparable to the control group. It is clearly observed that, dietary addition of antioxidants, could insignificantly affect the plasma albumin, albumin/globulin ratio and hepatic enzymes activities (AST and ALT enzymes) comparable to control group. In this respect, El-Mallah et al. (2011) showed that hens fed diet added with vit. E up to $0.50 \mathrm{mg} / \mathrm{kg} \mathrm{had}$ significantly $(\mathrm{P} \leq 0.05)$ increased blood serum total protein, albumin and globulin, whereas no effect $(\mathrm{P} \leq 0.05)$ on serum AST, ALT, triglycerides and glutathione peroxidase was detected comparing to the control group. These results supported those of Gursu et al. (2003) who found that serum activities of AST and ALT were not influenced by dietary vit. E supplementation. But through its known properties as an intra-membrane antioxidant, vit. E may protect tissue membrane from lipid peroxidation caused by free radicals attack. It could therefore reduce the associated loss of integrity of function of cell membranes and associated 
increased cellular permeability and play a role in alleviating the effect of heat stress in laying hens. Younis (2014) and Mobaraki et al. (2013) reported that the addition of vit. E affected triglyceride level in serum and the findings of (Ozcan et al., 2001) showed that dietary supplementary of vit. E affect the triglycerides level of chicks.

Table (5): Effect of adding some antioxidants to diet containing fatty acids on blood plasma proteins and lipids concentrations and liver functions of Silver Montazah laying hens at 36 weeks of age.

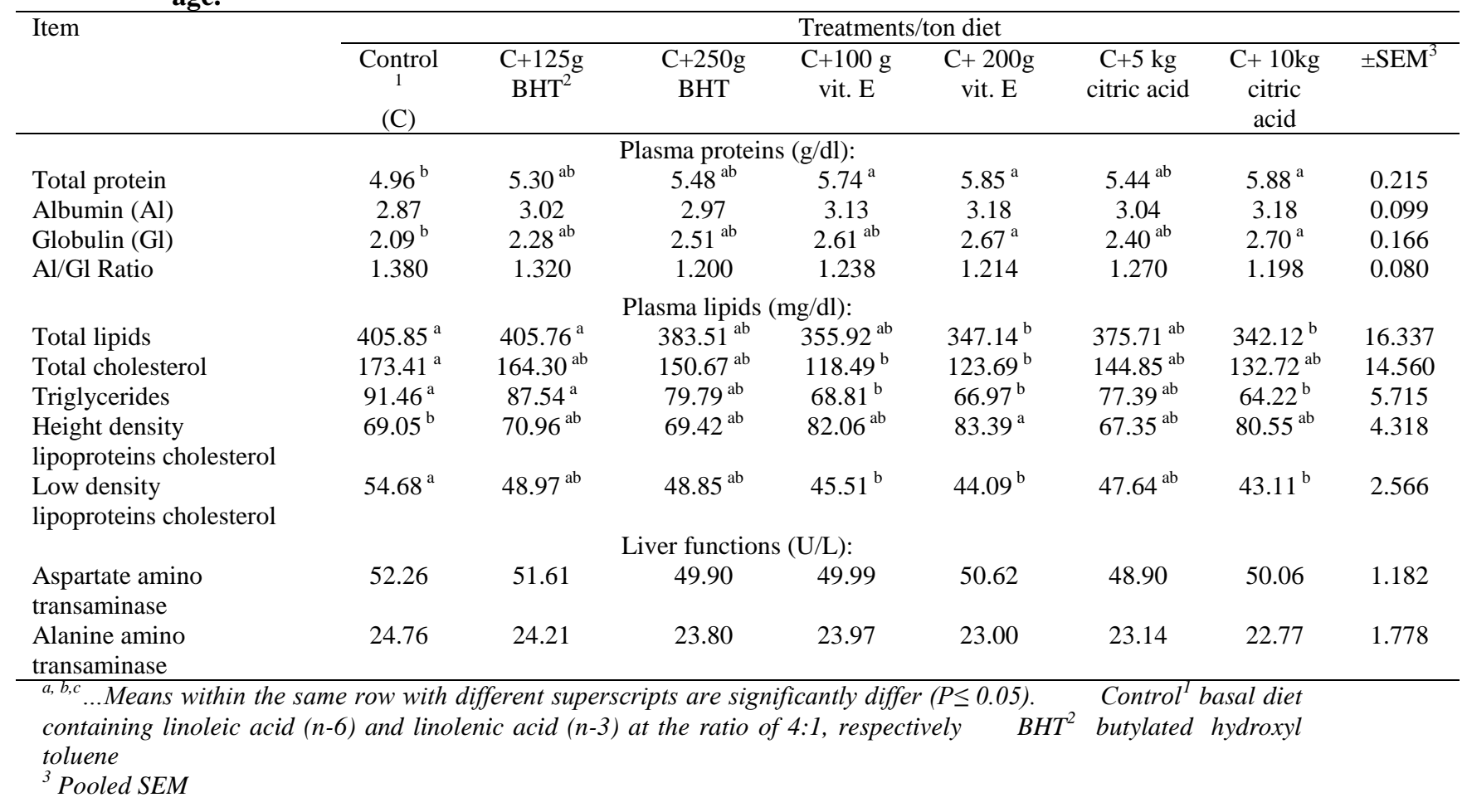

However, Abdel-Fattah et al. (2008) showed that the addition of 1.5 or 3\% CA increased the calcium and phosphors concentrations in the blood serum. However, CA did not affect the osteocalcin, or the blood serum content of $1,25(\mathrm{OH})_{2}$, vit. D or Ca of chickens fed a diet containing $0,0.25,0.75$ and $1.25 \% \mathrm{CA}$ (Islam et al., 2010). In addition, CA affected mineral utilization, but did not affect the plasma mineral contents (Nourmohammadi et al., 2010). These differences in the response to CA may be due to strain differences, dietary composition, hygienic conditions and the hormonal balance responsible for maintaining $\mathrm{Ca}$ and $\mathrm{P}$ homeostasis (Fraser, 1988).

There were increase in plasma total protein and globulin concentrations due to adding $0.2 \%$ CA to laying hens diet (Chowdhury et al., 2009; Das et al., 2011 and Islam, 2012). Chicks fed acidifiers have a better immune response, as evidenced by increased serum globulin and an allied increase in lymphoid organ weights when compared to a control group (Abdel-Fattah et al., 2008). Contradictory, El-Afifi et al. (2001) found a decrease in blood plasma protein with supplementation of different CA concentrations $(0.0 \%, 0.2 \%$, $0.4 \%, 0.6 \%$, and $0.8 \%$ ) to diet for broilers. In a subsequent study, El-Afifi (2003) cited that total plasma protein, albumin and globulin were not affected by CA. This contradiction in response to CA supplementation could be attributed to the CA concentration, dietary composition and hygienic conditions (Islam, 2012). However, Al-Harthi and Attia (2015) found that CA at $0.1 \%$ led to a significant increase in plasma albumin compared to $0.2 \% \mathrm{CA}$, a non-specific immune index compared to the other concentrations of CA. Similarly, Capcarova et al. (2014) found that CA did not negatively affect serum total protein but significantly increased serum albumin and decreased the albumin to globulin ratio.

\section{Semen quality:}

Data of the semen physical characteristics are shown in Table (6). Supplementation of some antioxidant to cock's diet at different types and levels caused a significant $(\mathrm{P} \leq 0.05)$ effect on all semen physical 
characteristics studied except semen $\mathrm{pH}$ and total abnormal sperm/ejaculate. However, adding some antioxidant to cock's diet especially BHT at the highest level ( $250 \mathrm{~g} /$ ton diet), vit. E at different levels (100 or $200 \mathrm{~g} / \mathrm{ton}$ diet) and CA at the lowest level (5 kg/ton diet) recorded higher values of ejaculate volume, sperm motility, live sperm percentage, sperm concentration, total sperm per ejaculate and total live sperm

Table (6): Effect of adding some antioxidants to diet containing fatty acids on semen quality traits of Silver Montazah cocks at 36 weeks of age.

\begin{tabular}{|c|c|c|c|c|c|c|c|c|}
\hline \multirow[t]{2}{*}{ Item } & \multicolumn{8}{|c|}{ Treatments/ton diet } \\
\hline & $\begin{array}{l}\text { Control }^{1} \\
\text { (C) }\end{array}$ & $\begin{array}{l}\mathrm{C}+125 \mathrm{~g} \\
\mathrm{BHT}^{2}\end{array}$ & $\begin{array}{l}\mathrm{C}+250 \mathrm{~g} \\
\mathrm{BHT}\end{array}$ & $\begin{array}{l}\mathrm{C}+100 \mathrm{~g} \\
\text { vit. } \mathrm{E}\end{array}$ & $\begin{array}{l}\mathrm{C}+200 \mathrm{~g} \\
\text { vit.E }\end{array}$ & $\begin{array}{l}\mathrm{C}+5 \mathrm{~kg} \\
\text { citric } \\
\text { acid }\end{array}$ & $\begin{array}{l}\mathrm{C}+10 \mathrm{~kg} \\
\text { citric } \\
\text { acid } \\
\end{array}$ & $\pm \mathrm{SEM}^{3}$ \\
\hline $\begin{array}{l}\text { Ejaculate volume } \\
(\mathrm{ml})\end{array}$ & $0.324^{b}$ & $0.342^{b}$ & $0.374^{\mathrm{ab}}$ & $0.434^{\mathrm{a}}$ & $0.472^{\mathrm{a}}$ & $0.400^{\mathrm{a}}$ & $0.384^{\mathrm{ab}}$ & 0.039 \\
\hline Semen $\mathrm{pH}$ & 7.40 & 7.38 & 7.81 & 7.62 & 7.80 & 7.43 & 7.57 & 0.233 \\
\hline $\begin{array}{l}\text { Sperm motility } \\
(1-5)\end{array}$ & $3.00^{\mathrm{b}}$ & $3.20^{\mathrm{ab}}$ & $4.20^{\mathrm{a}}$ & $4.20^{\mathrm{a}}$ & $3.60^{\mathrm{ab}}$ & $3.80^{\mathrm{ab}}$ & $3.20^{\mathrm{ab}}$ & 0.309 \\
\hline Live sperm \% & $83.60^{\mathrm{b}}$ & $80.00^{\mathrm{b}}$ & $91.20^{\mathrm{a}}$ & $88.00^{\mathrm{a}}$ & $89.00^{\mathrm{a}}$ & $83.60^{\mathrm{b}}$ & $83.40^{\mathrm{b}}$ & 2.110 \\
\hline Abnormal sperm \% & $17.60^{\mathrm{ab}}$ & $16.80^{\mathrm{ab}}$ & $14.00^{\mathrm{ab}}$ & $14.60^{\mathrm{ab}}$ & $12.60^{\mathrm{b}}$ & $16.60^{\mathrm{ab}}$ & $18.00^{\mathrm{a}}$ & 1.539 \\
\hline Sperm concentration & $3.280^{\mathrm{ab}}$ & $3.282^{\mathrm{ab}}$ & $3.782^{\mathrm{a}}$ & $3.808^{\mathrm{a}}$ & $3.646^{\mathrm{a}}$ & $3.582^{\mathrm{ab}}$ & $3.210^{\mathrm{b}}$ & 0.176 \\
\hline Total sperm/ejaculate & $1.054^{\mathrm{b}}$ & $1.134^{\mathrm{ab}}$ & $1.406^{\mathrm{ab}}$ & $1.620^{\mathrm{ab}}$ & $1.724^{\mathrm{a}}$ & $1.462^{\mathrm{ab}}$ & $1.240^{\mathrm{ab}}$ & 0.196 \\
\hline $\begin{array}{l}\text { Total live sperm/ } \\
\text { ejaculate }\end{array}$ & $0.892^{\mathrm{b}}$ & $0.928^{\mathrm{b}}$ & $1.286^{\mathrm{ab}}$ & $1.410^{\mathrm{ab}}$ & $1.534^{\mathrm{a}}$ & $1.248^{\mathrm{ab}}$ & $1.034^{\mathrm{ab}}$ & 0.176 \\
\hline $\begin{array}{l}\text { Total abnormal } \\
\text { sperm/ejaculate }\end{array}$ & 0.184 & 0.182 & 0.202 & 0.248 & 0.216 & 0.248 & 0.220 & 0.041 \\
\hline
\end{tabular}

per ejaculate compared to cocks of the other groups. On the opposite, adding CA at the highest level (10 $\mathrm{kg} / \mathrm{ton}$ diet) recorded the highest values of abnormal sperm percentage compared to cocks fed diet containing vit. E at the highest level (200 g/ton diet). In this respect, Abdallah et al. (2017) and Alm El-Dein et al. (2017) showed that supplementation of vit. E to cock's diet caused significant $(\mathrm{P} \leq 0.05)$ effect on all semen physical characteristics studied except semen $\mathrm{pH}$ at $60 \mathrm{wks}$ of age. Increasing sperm motility by dietary supplementation of vit. E may be due to vit. E decreases semen homocysteine which is a defective amino acid formed from demethylation of methionine and increasing homocysteine blocks intra-cellular proteincarboxyl methylation reactions results in inhibition of sperm motility (Sonmez et al., 2007). Results reported herein are similar to the conclusions drawn by Lin et al. (2005) who found that increasing level of vit.E from 40 to $160 \mathrm{mg} / \mathrm{kg}$ diet for Taiwan native cocks at 39 week of age significantly improved semen traits, particularly sperm livability and motility. Significant $(\mathrm{P} \leq 0.05)$ decrease of abnormal sperm percentage and increase sperm concentration by dietary supplementation of vit. E compared to control group may be due to the ability of vit. E as an antioxidant to resist the oxidative DNA damage and genetic alterations in the spermatozoa thus decrease abnormal sperm percentage (Bagachi et al., 1997). Also, Alm El-Dein et al. (2013) found that the highest level of vit. E (150 mg $/ \mathrm{kg}$ diet) improved the semen physical characteristics compared to the other low levels, according to the role of vit. E which, 1) reduces lipid peroxidation in seminal plasma and maintains an adequate viability of sperm to complete the fertilization process (Eid et al., 2006), 2) decreases semen homocysteine which is a defective amino acid formed from demethylation of methionine. The increased concentration of homocysteine blocks intra-cellular protein-carboxyl methylation reactions results in inhibition of sperm motility (Wallock et al., 2001 and Sonmez et al., 2007). Results obtained agreed with Lin et al. (2005) who demonstrated in 39 week old Taiwan native cockerels that, elevating the addition level of vit. E from 40 to $160 \mathrm{mg} / \mathrm{kg}$ diet plays a very significant role in improving semen traits, particularly sperm livability and motility,

On the other hand, Triques et al. (2016) showed that no effects of diet supplementation with the antioxidant blend were observed on semen volume and sperm motility, as well as vigor and concentration of roosters during the post-peak production phase. The observed percentages of normal sperm for both the control and antioxidant supplementation treatments were close to those reported by Łukaszewicz et al. (2008). 


\section{Fertility and hatchability:}

Significant effects of antioxidant treatments on fertility and hatchability percentages are shown in Table (7). Fertility percentage was significantly $(\mathrm{P} \leq 0.05)$ higher in vit. E treated group at the highest level $(200$ g/ton diet) than the control group. An increase of fertile eggs in antioxidant treated groups could be due to increase of ejaculate volume, sperm motility, live sperm\%, sperm concentration, total sperm/ejaculate and total live sperm/ejaculate compared with those in the control group. Also, hatchability percentage (hatchability of total eggs) was significantly $(\mathrm{P} \leq 0.05)$ higher in vit. E at the different levels $(100$ or $200 \mathrm{~g} /$ ton diet) groups compared to the control group. Moreover, hatchability percentage (hatchability of fertile eggs) was significantly $(\mathrm{P} \leq 0.05)$ higher in vit. $\mathrm{E}$ at the different levels $(100$ or $200 \mathrm{~g} /$ ton diet $)$ and $\mathrm{CA}$ at the

Table (7): Effect of adding some antioxidants to diet containing fatty acids on fertility and hatchability percentages of Silver Montazah laying hens at 36 weeks of age.

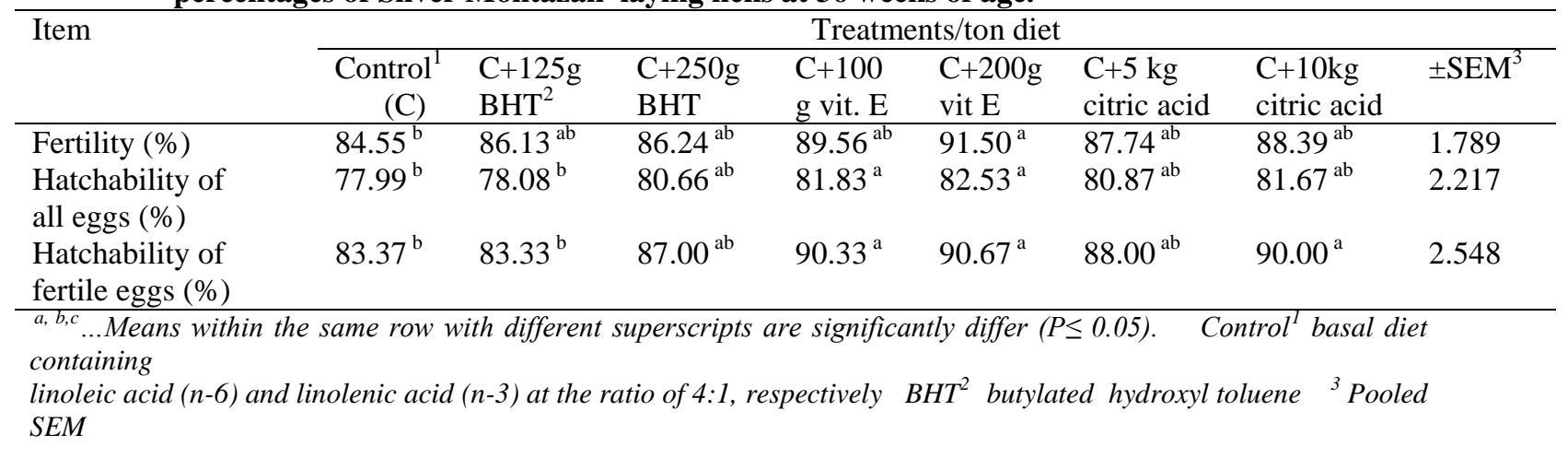

highest level (10 kg/ton diet) groups compared to the control group. Such increase may depend on egg shell thickness improvement in most antioxidant treated groups compared with the control group. In this respect, chicken spermatozoa are unique in their structure and chemical composition. The most important feature of lipid composition of the avian semen is the extremely high proportions of long-chain polyunsaturated fatty acids (PUFAs) in the phospholipid fraction of spermatozoa. On the one hand, the high PUFAs proportion is a necessity in order to maintain specific membrane properties (fluidity, flexibility, etc). On the other hand, spermatozoa became very susceptible to lipid peroxidation and, therefore, the antioxidant defence is considered to be a key element in maintaining semen quality. Vitamin E is located in spermatozoa and provides an antioxidant protection, especially in stress conditions of in vitro semen manipulation, including dilution, storage and deep freezing of spermatozoa (Surai, 2002). Furthermore, it was shown that vit. E provides additional protection in the case of fatty acid manipulation of the semen (Surai et al., 2000; Zanini et al., 2003 and Cerolini et al., 2005). However, in some studies the vit. E dose-response in cockerels was shown to be non-linear (Lin et al., 2005).

Alm El-Dein et al. (2017) found that fertility and hatchability percentage of both total and fertile eggs were increased by dietary vit. E compared to control group may be due to vit. E increase sperm motility as mentioned above in Table (6) and the motility is essential for sperm to traverse the vagina and reach the sperm storage tubules which is important for increasing fertility moreover, reduce lipid peroxidation in seminal plasma through reducing dexamethasone thus maintains an adequate viability of sperm which helping to complete the fertilization process (Eid et al., 2006). Also, vit. E through improving antioxidant status resulted in improving hatchability because oxidative metabolism increases during embryo development at hatchability process especially in the last few days before hatch, due to normal respiration related to embryo growth results in increasing the production of free radicals that doing lipid peroxidation leading to tissue damage and hatchability decline (Freeman and Vince, 1974). This concept is confirmed by Benzie (2003) who said that although oxygen is vital for most organisms but, simultaneously, considered damage key for biological sites and this damage is met by antioxidants substances. Also, Abdallah et al. (2017) found that dietary vit. E significantly $(\mathrm{P} \leq 0.05)$ increased the fertility and hatchability percentages from total eggs and/or hatchability from fertile eggs compared with those of the control, the concentration of vit. E (200 mg/kg diet) realized the best significant result of hatchability from total eggs and/or hatchability from fertile eggs compared with other groups. Also, Cerolini et al. (2005) reported that dietary supplementation of vit. E was associated with increased fertilizing ability of cockerels. 
The hatching process is considered to be a time of oxidative stress. Therefore, improved antioxidant defense during embryonic development potentially could increase hatchability. It was shown that vit. E can be transferred from the diet to the egg and consequently to the developing embryo (Surai, 2002). Increased vit. E concentration in the chicken embryonic tissues was associated with decreased tissue susceptibility to lipid peroxidation (Surai et al., 1999).

\section{CONCLUSION}

Dietary supplemental of some antioxidants to diet containing fatty acids is a practical application especially by 100 and $200 \mathrm{~g}$ vit. E or $10 \mathrm{~kg} \mathrm{CA} /$ ton diet to Silver Montazah chickens strain during the laying period and had beneficial effects on productive, reproductive, physiological and hematological parameters and immune status.

\section{REFERENCES}

Abdallah, E. A., Abd El-Samad, M. H., Abdel latif, A.M., Rezk, A.M. and Yassein Doaa M.M. 2017. Effect of dietary supplementation of grape seed extract or vitamin $\mathrm{E}$ as antioxidant on reproductive and physiological performance during summer season 2-Aged males developed chickens. Egypt. Poult. Sci., 37: 137-153.

Abdel-Fattah, S.A. and Abdel-Azeem, F. 2007. Effect of vitamin E, Thyroxin hormone and their combination on humoral immunity, performance and some serum metabolites of laying hens in summer season. Egypt. Poult. Sci., 27 (II):335-361.

Abdel-Fattah, S.A., El-Sanhoury, M.H., El-Mednay, N.M. and Abdul-Azeem, F. 2008. Thyroid activity of broiler chicks fed supplemental organic acids. Int. J. of Poult. Sci., 7:215-222.

Abd-El-Galil, M.A. and Abd El-Samad, M.H. 2004. Effect of vitamin E, C, Selenium and Zinc supplementation on reproductive performance of two local breeds of chickens under hot climate conditions. Egypt. Poult. Sci., 24(1): 217-229.

Alm El-Dein, A.K., Soliman, M.M. and Abd El-Aziz, S. 2013. Effect of dietary vitamin E supplementation on some productive, reproductive and immunological traits of Inshas chickens strain. Egypt. Poult. Sci., 33: 939-955.

Alm El-Dein, A.K., Rashed, O.S., Ouda, M.M.M., Awaden Nasra, B., Ismail Inas, I. and Mady M.S. 2017. Comparative study between dietary supplementation of grape pomace and vitamin $\mathrm{E}$ as antioxidant on some productive, reproductive and physiological performance of male and female aged Inshas strain chickens. Egypt. Poult. Sci., 37:855-872.

Al-Harthi, M. A. and Attia, Y. A. 2015. Effect of citric acid on the utilization of olive cake diets for laying hens. Italian J. of Anim. Sci., 14:39-66.

Bagachi, D., Garg A., Krohn, R., Bagachi, M., Tran, M. and Stohs, S. 1997. Oxygen free radical scavenging abilities of vitamin $\mathrm{C}$ and $\mathrm{E}$ and grape seed proanthocynidin extract in vitro. Res. Commun. Mol. Pathol. Pharmacol., 95: 179-90.

Benzie, I.F.F. 2003. Evolution of dietary antioxidants. Review. Comparative Biochemistry and Physiology, Part A 136: 113-126.

Bollengier-Lee, S., Mitchell, M.A., Utomo, D.B., Williams, P.E. and Whitehead, C.C. 1998. Influence of high dietary vitamin E supplementation on egg production and plasma characteristics in hens subjected to heat stress. Br. Poult. Sci., 39: 106-112.

Bollengier-Lee, S., Willams, P. E. V. and Whitehead, C. C. 1999. Optimal dietary concentration of Vitamin E for alleviating the effect of heat stress on egg production in laying hens. Br. Poult. Sci., 40: 102-110. 


\section{Bahakaim et al.}

Capcarova, M., Kalafova, A., Hrncar, C., Kopecky, J. and Weis, J. 2014. Comparative analysis of acetic and citric acid on internal milieu of broiler chickens. Potravinarstvo 8:190-195.

Carrillo-Dominguez, S., Avila, G.E., Vasquez, P.C., Fuente, B., Calvo, C.C., Carranco, J.M.E. and PerezGll, R.F. 2012. Effect of adding vitamin E to diets supplemented with sardine oil on the production of laying hens and fatty egg acid composition. African J. of Food Sci., 6: 12-19.

Cerolini, S., Surai, P. F., Speake, B. K. and Sparks, N. H. 2005. Dietary fish and evening primorose oil with vitamin E effects on semen parameters in cockerels. Br. Poult. Sci. 46: 214-222.

Chan, K. M. and Decker, E.A. 1994. Endogenous skeletal antioxidants Crit. Rev. Food. Sci. Nutr., 34:403426.

Cherian, G. 2007. Metabolic and cardiovascular diseases in poultry: Role of dietary lipids. Poult. Sci. 36: 1012-1016.

Chowdhury, R., Islam, K.M., Khan, M.J., Karim, M.R., Haque, M.N., Khatu, M. and Pesti, G.M. 2009. Effect of citric acid, avilamycin and their combination on the performance, tibia ash and immune status of broilers. Poult. Sci. 88:1616-1622.

Ciftci, M., NihatErtas, O. and Guler, T. 2005. Effects of vitamin E and vitamin C dietary supplementation on egg production and egg quality of laying hens exposed to a chronic heat stress. Rv. Med.Vet. 156: 107111.

Das S.K., Islam, K.M.S. and Islam, M.A. 2011. Efficacy of citric acid in diet contains low levels of protein and energy on the performance and immunity of broiler. pp 318-324 in Proc. $7^{\text {th }}$ Int. Poult. Show and Seminar 2011, Dhaka, Bangladesh.

Deepa, C., Jeyanthi, G.P. and Chandrasekaran, D. 2011. Effect of phytase and citric acid supplementation on the growth performance, phosphorus, calcium and nitrogen retention on broiler chicks fed with low level of available phosphorus. Asian J. Poult. Sci. 5:28-34.

Duncan, D. B. 1955. Multiple range and multiple F-test Biometrics, 11: 1-42.

Eid, Y., Ebeid, T. and Younis, H. 2006. Vitamin E supplementation reduces dexamethasone-induced oxidative stress in chicken semen. Br. Poult. Sci., 47: 350-356.

El-Afifi, Sh. F. 2003. Comparative studies on garlic bulb, virginiamycin, copper sulfate and citric acid as growth promoters in broiler chicks' diet. J. Agric. Sci. Mansoura Univ. 28:3423-3432.

EL-Afifi, Sh. F., EL-Medney, N.M. and Attia, M. 2001. Effect of citric acid supplementation in broiler diets on performance and intestinal microflora. Egypt. Poult. Sci., 21: 491-505.

El-Mallah, G.M., Yassein, S.A.1, Abdel-Fattah Magda, M. and El-Ghamry, A.A. 2011. Improving performance and some metabolic response by using some antioxidants in laying diets during summer season. J. of American Sci., 7(4).

El-Sheikh, S.E.M. and Salama, A.A. 2010. Effect of vitamin C and E as water additives on production performance and egg quality of heat stressed local laying hens in Siwa Aqsis. Egypt. Poult. Sci., 30: 679697.

Eng-elmann, D., Halle, J., Rauch, H. W., Sallmann, H.P. and Flachowsky, G. 2001. Influence of various vitamin E supplementation on performance of laying hens. Archiv-fur. Geflugelkunde. 65: 182-186.

Feed Composition Tables for Animal and Poultry Feedstuffs Used in Egypt, 2001. Technical Bulletion No.1, Central lab for Feed and Food; Ministry of Agriculture, Egypt.

Fraser, F.R. 1988. Bone minerals and fat-soluble vitamins. In: K. Blaxter and I. MacDonald (eds.) Comparative nutrition. John Libbey \& Company Ltd., London, UK, pp 105-112.

Freeman, B.M. and Vince, M.A. 1974. In: Development of the avian embryo. Champman and Hall, London, $\mathrm{Uk}, 249-260$.

Gordon, M. H. 1996. Dietary antioxidants in disease prevention. Natural Products Report in Bioorganic Chemistry, 14, 265-273. 
Gore, A. B. and Qureshi, M. A. 1997. Enhancement of humoral and cellular immunity by vitamin E after embryonic exposure. Poult Sci., 76: 984-991.

Gursu, M. F., Sahin, N. and Kucuk, O. 2003. Effects of vitamin E and selenium on thyroid status, adrenocorticotropin hormone and blood serum metabolite and mineral concentrations of Japanese quails reared under heat stress $\left(34^{\circ} \mathrm{C}\right)$.Trace Elem-Exp. Med.16: 95-104.

Islam, K.M.S. 2012. Use of citric acid in broiler diets. World. Poult. Sci. J. 68:104-118.

Islam, K.M.S., Haque, M.N., Chowdhury, R., Shahin, M.S.A. and Islam, K.N. 2010. Effect of citric acid administration through water on the performance of broiler fed commercial diet. Bangladesh J. Progr. Sci. Tech. 8:181-184.

Kahl, R. and Kappus, H. 1993. Toxicology of the synthetic antioxidants BHA and BHT in comparison with the natural antioxidant vitamin E. Zeitschrift fu“ $r$ Lebensmittel Untersuchung und Forschung, 196, 329338.

Kalamah, M.A., El-Nadi, M.M., Goher, L.M. and Soliman, M.M. 2000. Some factors affecting fertility and hatchability using artificial insemination in Norfa chickens. $3^{\text {rd }}$ All Africa Conference on Animal Agric. and $11^{\text {th }}$ Conference of the Egyptian Society of Animal Production, Alex. Egypt, 6-9 November, 597605.

Kaya, H., Kaya, A., Gul, M., Çelebi, S., Timurkaan, S. and Apaydin, B. 2014. Effects of supplementation of different levels of organic acids mixture to the diet on performance, egg quality parameters, serum traits and histological criteria of laying hens. European Poult. Sci., 78: DOI: 10.1399/eps.2014.46.

Kirunda, D.F.K., Scheideler, S. E. and Mckee, S.R. 2001. The efficacy of vitamin E (DL- $\alpha$-tocophyryl acetat) supplementation in hen diets to alleviate egg quality seterioration associated with high temperature exposure. Poult. Sci., 80:1378-1383.

Kristiansen, B., Linden, J. and Mattey, M. 1999. Citric Acid Biotechnology. Taylor and Francis Ltd. London, UK, PP 7-9.

Langhout, P. and Sus, T. 2005. Volatile fatty acids improve performance and quality. Int. Poult. Prod., 13:17-36.

Latshaw, J.D. 1991. Nutrition-Mechanisms of immunosuppression. Vet. Immunol. Immunopathol., 30: 111-120.

Lin, Y.F., Chang, S.J., Yang, J.R., Lee, Y.P. and Hsu, A.L. 2005. Effects of supplemental vitamin E during the mature period on the reproduction performance of Taiwan native chicken cockerels. Br. Poult. Sci., 46: 366-373.

Łukaszewicz, E., Jerysz, A., Partyka, A. and Siudzinska, A. 2008. Efficacy of evaluation of rooster sperm morphology using different staining methods. Veterinay Sci., Basel, v. 85, n. 3, p. 583-588.

Metwally, M. A. 2003. Effects of vitamin E on the performance of Dandarawi hens exposed to heat stress. Egypt Poult. Sci., 23(1):115-127.

Mobaraki, M. A, Shahryar, H.A. and Dizaji, A. A. 2013. The effects of vitamin E-Se supplemented on some of serum biochemical parameters in the laying Japanese quail. Bulletin of Environment, Pharmacology and Life Sciences. Vol. 2 (10) September: 29-32.

Nezhad, Y. E., Shivazad, M., Nazeeradl, M. and Babak, M. M. S. 2007. Influence of citric acid and microbial phytase on performance and phytate utilization in broiler chicks fed a corn-soybean meal diet. J. Fac. Vet. Med. Univ. Tehran. 61:407-413.

Nourmohammadi, R., Hosseini, R.M. and Farhangfar, H. 2010. Influence of citric acid and microbial phytase on growth performance and carcass characteristics of broiler chickens. Am. J. Anim. Vet. Sci., 5:282-288.

NRC. 1994. National Research Council, Nutrent requirements of poultry. $9^{\text {th }}$ Ed., National Academy press, Washington, D C.

Ozcan, S. K., Bent, E. Sørensen and Oved Yosha 2001. Economic integration, industrial specialization, and the asymmetry of macroeconomic fluctuations. J. of Int. Economics, 55: 107- 137. 


\section{Bahakaim et al.}

Packer, L., Tritschler, H.J. and Wessel, K. 1997. Neuroprotection by the metabolic antioxidant alpha-lipoic acid. Free radical Biology Medicine, 22: 359-378.

Panda, A.K., Ramarao, S.V., Raju, M.V.L.N. and Chatterjee R.N. 2008. Effect of dietary supplementation with vitamin $\mathrm{E}$ and $\mathrm{C}$ on production performance, immune responses and antioxidant status of White Leghorn layers under tropical summer conditions. Br. Poult. Sci., 49:592-599.

Puthpon-Gsiriporn, U., Scheideler, S. E., Sell, J. L. and Beck, M. M. 2001. Effects of vitamin E and C supplementation on performance, in vitro lymphocyte proliferation, and antioxidant status of laying hens during heat stress. Poult. Sci., 80 (Suppl. 8):1190-1200.

Radwan Nadia, L., Abd El-Samad, M.H. and Nada Sherin, A. 2012. Effects of different dietary ratios of linoleic acid to A-linolenic acid on productive performance, immunity of laying hens and yolk fatty acid composition. Egypt. Poult. Sci., 32:163-188.

Sahin, K., Sahin, N. and Onderci, M. 2002. Vitamin E supplementation can alleviate negative effects of heat stress on egg production, egg quality, and digestibility of nutrients and egg yolk mineral concentrations of Japanese quails. Res. Vet. Sci., 73:307-312.

SAS, institute 2001. SAS Users Guide Statistics Version 10 ${ }^{\text {th }}, 16-$ Edition, SAS Inst., Cary, NC.

Sijben, J.W.C., deGroot, H., Nieuwland, M.G.B., Schrama, J.W. and Parmentier, H.K. 2000. Dietary linoleic acid divergently affects immune responsiveness of growing layer hens. Poult. Sci., 79:1106-1115.

Sonmez, M., Yuce, A. and Turk, G. 2007. The protective effect of melatonin and vitamin E on antioxidant enzyme activates and epididymal sperm characteristics of homocysteine treated male rats. Reproductive Toxicology, 23: 226-231.

Surai, P.F. 2002. Natural Antioxidants in Avian Nutrition and Reproduction. Nottingham University Press, Nottingham.

Surai, P.F., Noble, R.C. and Speake, B.K. 1999. Relationship between vitamin E content and susceptibility to lipid peroxidation in tissues of the newly hatched chick. Br. Poult. Sci., 40: 406-410.

Surai, P.F., Noble, R.C., Sparks, N.H.C. and Speake, B.K. 2000. Effect of long-term supplementation with arachidonic or docosahexaenoic acids on sperm production in the broiler chicken. J. Reprod. Fertil. 120, 257-264.

Triques, G. E., Joice, M. S., Camila, S. O., Heloísa, F. B., Daiane, G. D. and Jovanir, I. M. F. 2016. Effect of dietary antioxidant supplementation on reproductivencharacteristics of male broiler breeders during the post-peak production phase. Semina: Ciências Agrárias, Londrina, v. 37, n. 4, suplemento 1, p. 25572566.

Vertuani, S., Angusti, A. and Mafredini, S. 2004. The antioxidant and pro- antioxidant network: An overview. Current Pharmaceutical Design, 10: 1677-1694.

Vogt, V. 2001. The effect of sodium butyrate on the technical performance in layers. Proc. 13th Eur. Symp. on Poult. Nutr., Bremen, Germany.

Wallock, L.M., Amura, T., Mayr, C.A., Johnston, K.E., Ames, B.N. and Jacob, R.A. 2001. Low seminal plasma folate concentrations are associated with lowsperm density and count in male smokers and nonsmokers. Fertility and Sterility, 75: 252-259.

Younis, D. Th. 2014. Effect of antioxidant enhancement on productive performance and some physiological characters of broiler breeders reared under hot climate. Iraqi J. of Vet. Sci., 28 (2): 81-85.

Zanini, S. F., Torres, C. A., Bragagnolo, N., Turatti, J. M., Silva, M. G. and Zanini, M. S. 2003. Evaluation of the ratio of omega 6 :omega 3 fatty acids and vitamin E levels in the diet on the reproductive performance of cockerels. Archiv fur Tierernahrung, 57: 429-442. 
تأثير إضافة بعض مضادات الأكسدة لعليقة تحتوى على الأحماض الأهنية على الأداء الإنتاجي وبعض القياسات

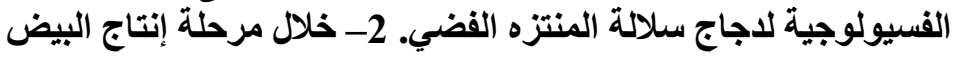

\author{
أحمد سعد أحمد باحكيم² و إبراهيم تحمل عساف1 و سحرمحم حامد عثمان1 و محمد محمود سليمان2 و و أحمد محم بعيلش2

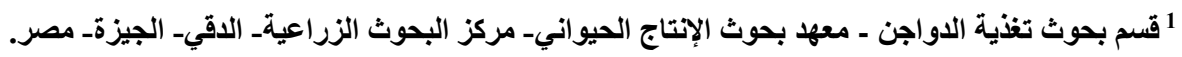

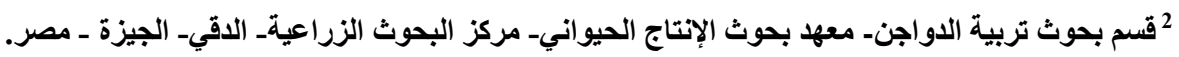

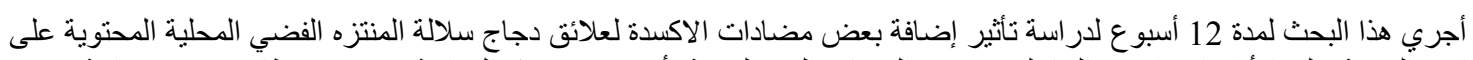

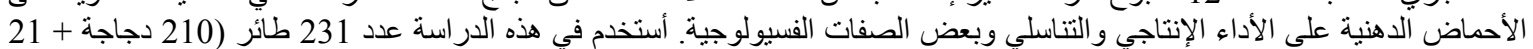

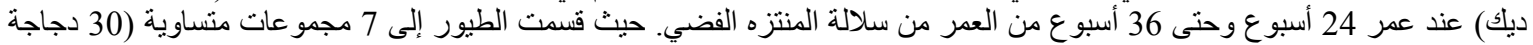

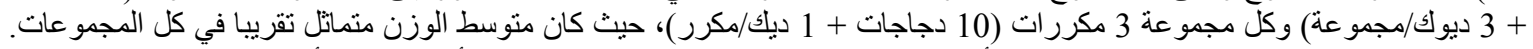

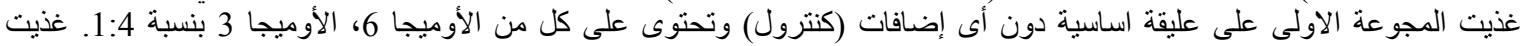

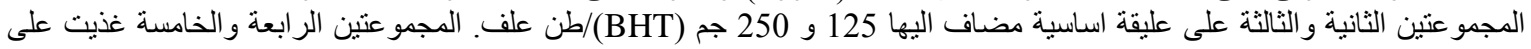
عليقة اساسية مضاف اليها 100 و 200 جم فيتامين E/طن علف. المجموعتين السادسة و السابعة غذيت على عليقة اساسية مضاف اليها 5 و 10 كجم حمض الستريك /طن علف، بالترتيب.

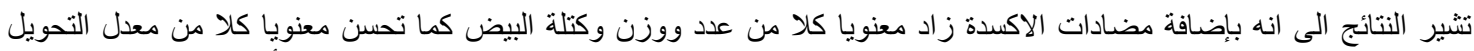

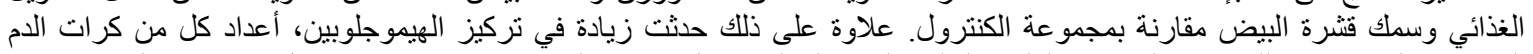

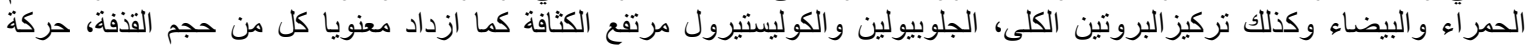

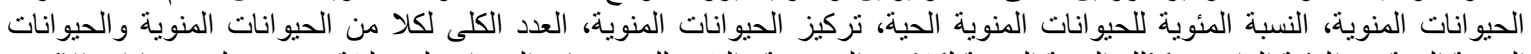

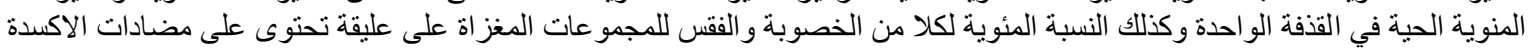

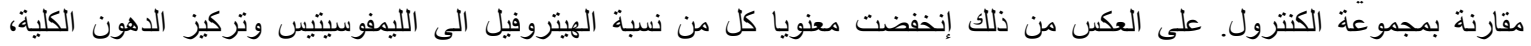

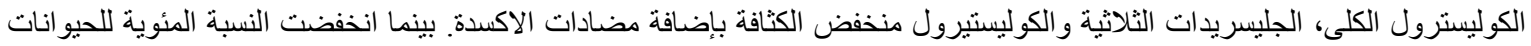
المنوية الثاذة لجميع المعاملات مقارنة بالكنترول.

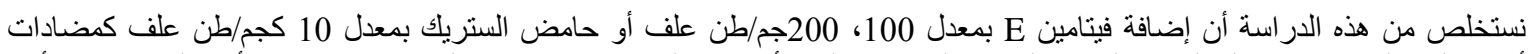

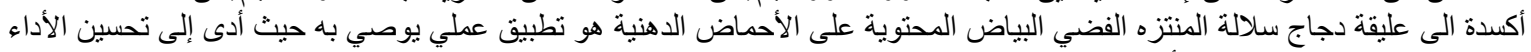

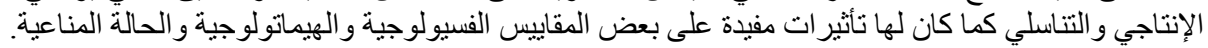

